\begin{tabular}{|l|l|l|}
\hline \multicolumn{2}{|c|}{ PublisherInfo } \\
\hline \hline PublisherName & $:$ & BioMed Central \\
\hline \hline PublisherLocation & $:$ & London \\
\hline \hline PublisherImprintName & $:$ & BioMed Central \\
\hline \hline
\end{tabular}

\title{
Inventory of secreted proteins
}

\begin{tabular}{|l|l|l||}
\hline \multicolumn{2}{|c|}{ ArticleInfo } \\
\hline \hline ArticleID & $:$ & 4494 \\
\hline \hline ArticleDOI & $:$ & $10.1186 /$ gb-spotlight-20020530-01 \\
\hline \hline ArticleCitationID & $:$ & spotlight-20020530-01 \\
\hline \hline ArticleSequenceNumber & $:$ & 160 \\
\hline \hline ArticleCategory & $:$ & Research news \\
\hline ArticleFirstPage & $:$ & 1 \\
\hline \hline ArticleLastPage & $:$ & 2 \\
\hline \hline & & RegistrationDate : 2002-5-30 \\
\hline ArticleHistory & $:$ & OnlineDate \\
\hline \hline ArticleCopyright & $:$ & BioMed Central Ltd2002-50 \\
\hline \hline ArticleGrants & $:$ & \\
\hline \hline ArticleContext & $:$ & 130593311 \\
\hline \hline
\end{tabular}




\section{Jonathan B Weitzman}

Email: jonathanweitzman@hotmail.com

The pathogenicity of Pseudomonas syringae pv tomato DC3000 depends on effector proteins that are injected into the host plant cell by the Hrp (hypersensitivity response and pathogenicity) type III protein secretion system. In the May 28 Proceedings of the National Academy of Sciences, Petnicki-Ocwieja et al. report an analysis of the DC3000 genome to identify new Hrp-dependent proteins (Proc Natl Acad Sci USA 2002, 99:7652-7657). They found homologs of avirulence (Avr) proteins and potential effector candidates by mining the DC3000 genome for genes downstream of Hrp promoter sequences. Many of these proved to be secreted by the DC3000 Hrp system. In addition, comparative sequence analysis allowed them to predict Hrp-secreted proteins on the basis of export signal motifs. These two approaches led Petnicki-Ocwieja et al. to identify a number of novel Hops (Hrp-dependent outer proteins) that may be linked to pathogenicity.

\section{References}

1. Proceedings of the National Academy of Sciences, [http://www.pnas.org]

2. TIGR Microbial Database, [http://www.tigr.org/tdb/mdb/mdbinprogress.html] 